\title{
School Architecture and Complexity
}

\author{
RENA UPITIS \\ Queen's University
}

Recent studies document the importance of well-designed facilities on the academic performance of students in language and mathematics, but there is very little research on how space dictates what is learned and how it is learned. What about learning that is not directly measurable by standardized test scores? How does architectural space affect what is learned in the "non-core" disciplines such as music, drama, dance, and the visual arts? How does the built environment affect the ways that teachers and students operate in what might be viewed as a learning collective? These are some of the central questions addressed in the present paper. These issues are first explored through a brief discussion of the main themes in school architecture research and discourse, followed by a description of how Froebel kindergartens, Reggio Emilia schools, and Waldorf schools have given attention to some of the physical elements that affect learning. Next, I explore engaging forms of adult learning and the perspectives of John Dewey. Then follows a discussion of the ways that classrooms and schools can be seen as collectives, using complexity science theory as a theoretical framework. Finally, the complexity science model is extended by including the actual physical spaces as important 'agents' in influencing a non-linear and dynamic system, and by drawing implications for school design based on the principles of complexity. 
We shape our buildings, and afterwards our buildings shape us.

- Winston Churchill

This is an ideal time to re-think our notions about school architecture. We are in the middle of a new surge in school construction and renovation as schools built in the 1950s and 1960s to accommodate the baby boom are being retrofitted and new schools are being built to accommodate the baby boom echo. An often quoted statistic from the United States General Accounting Office (1995) suggests that billions upon billions of dollars still need to be spent to upgrade existing schools. Current estimates suggest that between 2000 and 2007, a further 5,000 schools will be or have been built in the United States alone (Plympton, Conway, \& Epstein, 2000). Put another way, in the United States, on average, construction on two new school buildings begins every day.

It seems self-evident that the kinds of buildings that children and their teachers inhabit will affect not only what they learn but also the ways in which they learn. It has been observed that for nearly two centuries, public schools have been built largely as a reflection of the factory model for learning: put a homogeneous group of children in a confined space (called a classroom), process them for a year (fill them with knowledge), make sure they have learned the set and predictable curriculum (test them according to established standards), move them to the next processing container (another classroom), and continue the cycle until they have reached the age at which they are deemed ready to leave (and enter the workplace). A vast number of people-architects and educators alike- have called this model into question (Boss, 2001a; Bullock \& Foster-Harrison, 1997; Davis, 2004; Day, 2000, 2001; Fiske, 1995; Gardner, 1999; Lamm, 1986; Nair, 2002; Papert, 1993). Not only does this model, and the buildings that go with it, perpetuate a linear and predictable image of learning, but it also perpetuates ways of thinking about complex disciplines-such as mathematics and science-that are limited and incomplete, thereby also perpetuating false distinctions between so-called scientific and humanist pursuits (Davis \& Sumara, in press).

Factory schools embody the transmission model of learning: the teacher has the knowledge, and in assembly line fashion transmits that knowledge to the students. Then students are tested as to whether they have retained the knowledge that has been presented to them. Despite the many new theories of learning that have been spawned over the past century-including Dewey's progressivist notions, to which I will soon return-factory schools and transmission teaching remain. Is it the case that teachers are not able to move away from the transmission model that they know so well and that governments continually reinforce through high-stakes testing and subsequent funding decisions? Or are there other reasons that school teaching 
remains indelibly marked by transmission methods? A central premise of this paper is that the buildings in which we house students and teachers play a large role in perpetuating the transmission model of teaching, despite the alternative models of teaching and learning that have been proposed and analyzed and discussed and modeled by educators, researchers, and psychologists for the past century.

Further, I would argue that the buildings we call schools not only perpetuate a transmission model of learning, but that they also favor the teaching of so-called "core" subjects—subjects like mathematics and languageover subjects like music, art, dance, and gardening. It's not that the teachers don't want to do more with the arts or teach children more about the natural world: often they simply can't do so with the buildings and grounds at their disposal. In recent research that I conducted on teachers' views and practices in arts education, I was struck by how frequently teachers indicated that they would like to do more with the arts curricula but were unable to because it was difficult to find enough time to use the gym or because studio or performance spaces were simply not available (Upitis, 2001; Patteson, Upitis, \& Smithrim, 2002). Perhaps not coincidentally, it is also the case that these forms of learning-learning about the natural world, learning in and through the arts - are not as amenable to being testing by standardized, paper-and-pencil methods.

\section{School Architecture}

There is nothing new about the idea that much of what we learn from the architecture of our schools - and other public buildings, for that matter-is a reflection of larger cultural values (Bingler, 1995; David \& Weinstein, 1987). Indeed, Bradley (1998) argues that in the times before the printing press, buildings were a primary medium for communication, giving the example of the medieval cathedral as a "testament in stone and glass to the teachings of Christian thought." Bradley further argues that "whether in the plan and elevation or in the sculpture and ornamentation, the building conveyed meaning." Taylor (1995) talks about the transmission of cultural values through architecture in more general terms, stating that "we expect schools to prepare children for living in a democratic society, yet we provide a learning environment that resembles a police state-hard, overly durable architecture, giant chain-link fences, locked gates, guards, and even guard dogs. Such architecture fails to encourage the sense of ownership, participation, or responsibility required for a democracy." (p. 69).

Other ways that learning is affected by architecture are more directly related to the formal curriculum. Researchers conclude, more often than not, that students who attend schools that are well maintained, meet safety 
standards, and are kept clean, are also more likely to demonstrate higher levels of academic performance than those students in schools with leaking roofs, broken windows, missing toilet stalls, and dark classrooms (Berner, 1992, 1995; Boss, 2001a; Kolleeny, 2003; Lezotte \& Passalacqua, 1978; Peters, 2003). For decades, engineers, architects, psychologists, and educators have also examined the role that lighting and color, for instance, play in generating environments conducive to learning and to prosocial behaviors (Dudek, 2000; Hathaway, 1995; Luckiesh \& Moss, 1940; Muir, 2001; Rice, 1953; RittnerHeir, 2002; Romney, 1975; Sherman, 2001; Tanner, 2000). Some researchers and planners have demonstrated that the use of daylight in the context of a larger energy-efficient design is not only associated with higher levels of student performance, but can also be cost effective (Hathaway, 1995; Plympton, Conway, \& Epstein, 2000; Reicher, 2000). Studies have also focused on the detrimental effects of too much noise in the learning environment (Boss, 2001a; Chan, 1980; Tanner \& Langford, 2003), the importance of appropriate furniture (Bullock \& Foster-Harrison, 1997), and the need for inviting outdoor spaces including green areas and play areas (Tanner, 2000). It is sobering to realize that many of these elements-including the importance of good light and ventilation, proper furniture, and the need for green spaces-were recognized as crucial elements by the first American Commissioner of Education, Henry Barnard (1848), in his classic work on school architecture written over 150 years ago.

Over the past decade, architects and school planners have turned their attention to the importance of involving a number of stakeholders in the design process (Bingler, 2001; Carey, 2001; Day, 2001; Hill, 1997; Hyer, 2001; Tanner, 2000; Taylor, 1995). This is a welcome trend, and one that I will return to later in the paper. But this trend towards broad consultation is not enough - the admirable attempt to consult fully, and early in the process, will fail to produce schools that are markedly different than the ones we now know unless we also acknowledge that our ways of viewing teaching and learning are incomplete.

\section{Architecture and Arts-based Schooling in the Early Years}

For the architect and philosopher Rudolf Steiner, architectural principles shaped the development of his Waldorf schools as much as pedagogical ones. Froebel, the originator of Froebel kindergartens, was a student of architecture as well, and echoes of the influences of his architectural thinking are still present in many contemporary kindergartens (Dudek, 2000). Reggio Emilia schools also focus on the physical space. I examine these three approaches, not necessarily to contrast them or to show similarities between them, but to illustrate that, at least in early childhood, there is already a sensitivity to how 
architecture shapes and teaches the child-a sensitivity that is subsequently lost as the child progresses through the standard elementary, middle, and high school classrooms of most North American schools.

Teachers in the preprimary schools of Reggio Emilia focus explicitly on what school environments teach children. In most Reggio Emilia preprimary schools, there are two teachers, and it is common for educators to use the term "third educator" to describe the school building as teacher (Gandini, 1998; Tarr, 2001). Reggio Emilia environments are based, in part, on the schools' embracing of Dewey's educational philosophy, and as such, teachers believe that the best environments for children are rich and complex, support relationships between people and ideas, and have a strong aesthetic appeal for teachers and students alike (Borgia, 1991; Tarr, 2001). As a result, Reggio schools bring elements of the home into the school, what Tarr calls "beautiful objects in their own right". Tarr claims that Reggio educators carefully consider the physical environment in light of its educational potential, both in terms of the objects in the environment and in terms of the kinds of spaces for inquiry, such as the atelier. Tarr writes:

I was struck by the beautiful wooden table with a large bowl of flowers and wooden sideboard in one of the rooms in La Villetta School ... Manufactured and natural materials available for art projects are carefully displayed in transparent containers, or objects are set on or before mirrors to provide multiple views and capture children's attention. The strong role of the arts in Italian culture is clearly evident in the place of the atelier (art studio), mini ateliers adjacent to each classroom and the role the atelierista (artistteacher) plays in supporting children and teachers in their work. The typical North American classroom reflects notions of preparation for the future world of work [with] simplified visual forms [that] protect children from the outside world. Its visual aesthetic reflects mass marketing and craftstore culture. It does not challenge children aesthetically to respond deeply to the natural world, their cultural heritage, or to their inner worlds.

Froebel's kindergartens also emphasized the exterior learning spaces (Herrington, 2001). Froebel himself grew up in a largely rural environment, and in addition to his studies in architecture, was also a student of biology, mathematics, and forestry. He emphasized the importance of indoor and outdoor play for learning. Unity with nature was also a central theme for Froebel (Dudek, 2000). As a result of Froebel's emphasis on play, his kindergartens contained specially designed materials to be used by the children to manipulate objects and create structures, materials referred to as "gifts and occupations" (Dudek, 2000). Among Froebel's gifts and occupations were wooden forms for three-dimensional design work, clay modeling materials, and paper folding. The influence of Froebel and his "gifts and occupations" have been widely attributed as foundational influences for Frank Lloyd Wright. 
Dudek (2000) goes so far as to suggest that the $20^{\text {th }}$ century view of modern architecture stemmed directly from the many hours Wright spent manipulating Froebel's gifts. Wright himself acknowledged this debt; he claimed that "the maple wood blocks [were] in his fingers" throughout his professional life (http:/ / www.geocities.com/Athens/Forum/7905/web2000.html; retrieved on 2004 Mar 10). The relationship between Wright's early schooling and subsequent ideas about building design is explored at length by Rubin (2002). But what I find most interesting about the influences of Froebel's gifts on Wright's thinking is that it points to the natural affinity between the structures of architecture and the explorations of childhood.

Rudolf Steiner-known for architecture referred to as organic expressionism, where buildings were "liberated from the constraints of the right angle" (Dudek, 2000, p. 62)—established the first Waldorf schools. Waldorf education is now one of the fastest growing independent school movements in the world. For Steiner, every aspect of the school-the wooden furniture, pastel colors, natural lighting, and the presence of natural objects in the classrooms, as well as the outdoor spaces-had architectural and pedagogical significance (Oberman, 1997; Rudolf Steiner Farm School, 1979). Perhaps it is partly for these reasons-attention to color, furniture, and the natural world-that the Waldorf curriculum is quite different from the curriculum that one finds in public schools. Waldorf schools are often described as arts-based. Not only is there an emphasis on learning in the arts themselves (e.g., water color painting, beeswax modeling, playing musical instruments, singing), but the core subjects-like language and mathematics-are approached through artistically embodied means. These means include drawing, story, chant, and a choreographed series of body movements known collectively as "eurythmy" (Oberman, 1997). Another feature of Waldorf schools is that they operate without a formal administrative structurethere are, for example, no school principals. Rather, decisions are made by the teaching faculty as a whole; there are "no directing mechanisms that meet the eye" (Oberman, 1997, p. 3). This notion of decentralized control figures prominently in complexity science, a theoretical view that will be discussed later in the paper.

\section{When No One is Watching: Adult Learning and Dewey}

When adults are asked to think of something they love to do-a passion or a hobby that gives them both pleasure and moments of intense strugglemost people will identify a form of learning that is connected with the arts, the body, or the natural world (Upitis, 2003a). Why is it that learning in the arts, learning that involves the body, and learning that involves intimate interactions with the natural world, are so important to our out-of-school 
learning? The learning that we do when no one is watching? I have come to believe that what playing the guitar and hiking in the mountains have in common is that they have the potential to fully engage the intellect, the emotions, the physical body, and that elusive part of us known as the spirit or soul. These kinds of activities and learning connect us with the earth and with what it means to be human. I think of this kind of learning as romantic - characterized by fear, ambiguity, excitement, flexibility, uncertainty, sensuality, struggle, exploration and surprise (Upitis, 2003b). The passion and seriousness with which people engage in the learning that they do when no one is watching (or testing) is precisely the passion that is required to nurture and sustain meaningful learning in schools. But do we have the kinds of schools that can sustain such learning?

At the turn of the $20^{\text {th }}$ century, Dewey claimed that four things were important to children: "conversation; ... inquiry; ... making things;... and artistic expression" (Dewey, 1900/1956, p. 47) Dewey described in detail how children's first impulses to learn are through play, through movement, through the imaginary worlds of "make-believe" (p. 44). He observed that the instinct for investigation or inquiry grew out of "constructive impulses," noting how there was "no distinction between experimental science for little children and the work done in the carpenter shop" (p. 44). He argued that, carefully channeled, the instincts to investigate and to make things could lead to substantive and deeply embodied learning. Dewey spoke of the expressive or artistic impulse in children as being the full manifestation of the instincts to construct and communicate. He claimed that in situations where the artistic impulse was nurtured, meaningful relationships and patterns were learned and artistic work was produced (1900/1956).

Dewey also had something to say about schools. In the early 1930s, he imagined what he called the "utopian" school. Dewey began his discussion of schools "not with issues of pedagogy or teacher method or administration, but with physical space." (Uline, 1997, p. 196). Dewey wrote about large grounds, gardens, and greenhouses. He described "open-air" interiors, the importance of having a variety of workspaces, easy access to books, and the feeling of a "well-furnished home". Dewey was "not shy about emphasizing beauty and comfort and excitement" (Uline, 1997, p. 196).

Bruce Jilk, former chair of the American Institute of Architects Committee on Architecture for Education, has embraced the teachings of Dewey and created a series of design principles to help create innovative learning environments. One such environment is the Minnesota School of Environmental Studies, located on the grounds of the Minnesota Zoological Gardens (Boss, 2001a; Bingler, 2002). In that school, 400 Grade 11 and 12 students pursue various interdisciplinary projects with the kinds of inquiry that Dewey must have envisaged. In a similar vein, the Edible Schoolyard, 
a central feature of the once derelict Martin Luther King Middle School in Berkeley, California, offers students opportunities for conversation, inquiry, making and the culinary arts at their finest (Boss, 2001b). The idea of these schools-which include both built and natural environments-is not to teach children about zoology or horticulture per se, but to provide rich settings for exploration, and for discovering things that are unanticipated by student and teacher alike.

It is long past time for us to imagine education and curriculum that was driven by artistic expression, by making things, by inquiry, by conversation, and by being surrounded by beauty and by the natural world. One cannot help but believe that these are the very things that drive meaningful and romantic learning at all levels-from the early years through to the pursuits that adults engage in throughout their lives.

\section{Complexity Science and Education}

In the opening of this paper, I claimed that the prevalent model for teaching and learning is that of transmission and that the design of schools is complicit in perpetuating this model. However, many of the other ways of learning and teaching have been discussed by philosophers, psychologists and educators over the past century move away from teacher-centered to more learner-centered ways of knowing. A more recent theory to account for learning - particularly learning in classrooms and other forms of learning communities - is offered by the field of complexity science. This is a theory of learning that has yet to reach the mainstream of educational discourse. But it has extraordinary promise-and implications for architecture that are profound.

Complexity science first arose as a defined field of study in the latter part of the $20^{\text {th }}$ century when various branches of science and mathematics evolved into new areas such as fractal geometry (Capra, 1996; Davis, 2004: Johnson, 2001; Maturana \& Varela, 1998). It has since been applied to various phenomena in the social sciences. Complexity science is the study of adaptive and self-organizing systems (Davis, 2004). That is, complexity science seeks to understand phenomena that organize, in some way, in a bottom-up collective-collectives such as ant colonies, pigeon flocks, and trends in the stock market-collectives where there is no single agent or orchestrator in control of the whole (Davis, 2004; Johnson, 2001). Rather, complexity theory explains how such dynamic systems function when there are many 'agents' or members interacting in ways that are both predictable and random. These systems that are therefore capable of giving rise to new levels of order-that is, of learning. As Davis puts it, "Self-organized, self-maintaining forms can arise and evolve without goals, plans, or leaders." (p. 151). 
Because complexity science theory seeks to explain how a system, as a whole, functions when there are multiple agents involved in some form of self-organization, educators have recently applied this orientation to describe and explain various learning collectives, including the collective that is known as the classroom. In thinking of learning systems, Davis argues that using the complexity science framework, the notion of "learner" goes beyond the individual to include also "social cliques and other clusters that arise in any student body, the classroom collective, the school, [and] the community" (p. 105). As Davis further adds, "Teachers commonly refer to classrooms of learners as coherent unities that have intentions, habits, and other personality traits." (p. 168).

Educators have now begun to use complexity theory to show how the relationships of individuals, collectives, ideas, and curriculum can be thought of as nested learning communities (Davis, 2004; Fleener, 2002). Further, by extending the notion of learner into these nested contexts, it means that both biological and cultural systems shape and are shaped by the learner(s) (Davis, 2004; Lakoff \& Johnson, 1999; Tomasello, 2000). For millennia, the biological bases of knowing have been either ignored or suppressed within most Western discussions of knowledge and teaching: complexity science offers one way of bringing those influences back into the discourses of teaching and learning (Davis, 2004). It also means that such a theoretical framework might bring our understanding of learning closer to those romantic ways of knowing that we engage in of our own free will-and back to the importance of the natural world in educational settings as recognized by Froebel and Steiner.

Several key principles have been identified in explaining complex collectives, including neighbor interaction (Davis \& Upitis, 2004; Johnson, 2001), redundancy among the agents (Davis, 2004), diversity in the system (Davis, 2004), pattern recognition (Johnson, 2001), feedback (Johnson, 2001), and liberating constraints (Davis, 2004). Complex systems also have indirect control (Johnson, 2001) or decentralized control structures (Davis, 2004). As Davis claims, decentralized control is not meant to be a condemnation of the teacher-centered classroom (or factory/transmission model) nor as an endorsement of student-centered forms of learning that have enjoyed such prominence in the last few decades.

Rather, it represents a critique of an assumption that is common to both those structures-namely, that the site of learning is the individual. As complexity science asserts, the capacity to learn is a defining quality of all complex unities. Thus one must be clear on the nature of the complex unities that are desired in the classroom. Such unities are concerned with the generation of knowledge and the development of understanding - meaning that the focus should not be on teacher or learners, but on collective possibilities for interpretation. (Davis, 2004, pp. 169-170). 
This means that teaching is unpredictable. That it cannot be prescribed or orchestrated. That teaching - even with the framework of complex emergence- "cannot be managed into existence" (Davis, 2004, p. 170). It means, instead, that teaching must be conceived of as a form of engaged attentiveness and responsiveness to others who are involved in the collective. It also means that teachers must "establish a balance between sufficient organization to orient learners' actions and sufficient openness to allow for the varieties of experience, ability and interest represented in any classroom." (Davis, 2004, p. 182).

At the most recent Complexity Science and Educational Research Conference, held in October, 2004, (http: / / www.complexityandeducation.ca), one of the issues that continually emerged was that teaching and learning were about expanding the space of the possible, and in so doing, creating conditions for things that have not yet been learned nor imagined, for surprise, for evolution through the known to the unknown. In order for complexity to emerge, there must be redundancy and diversity, as mentioned previously, but there must be, also, "opportunity for diverse ideas to interact, to harmonize, and to amplify one another. History is rife with examples of ideas bumping against one another to give rise to new, more powerful interpretive possibilities ... This sort of dynamic is present in every significant advance in human knowing." (Davis \& Upitis, 2004, p. 126).

If this is teaching and learning, then what kinds of physical spaces would provide the right forms of enabling constraints for complexity to emerge? For children and teachers to play a part in advancing knowledge? It is to this issue that I now turn.

\section{Complexity Science, Architecture, and Schooling}

In the previous section, I argued that complexity science offers a theoretical frame for thinking about learning and teaching in ways that might more fully represent the 'romantic' learning that I believe schools should foster. This means fostering not only individual learning, but also, learning by collectives, such as classrooms or groups of people interested in particular ideas, and learning about curriculum structures or disciplinary knowledgeanother form of collective.

What are the implications for designing schools if one is to include not only the people, ideas, and curriculum involved in learning, but also, the actual physical spaces, both built and natural, as important 'agents' in influencing a complex system? I now turn to a preliminary formulation of some of the architectural patterns that would need to be considered if learning was thought of in terms of complexity science, and if the buildings themselves were considered to be a part of the system. I also consider the mecha- 
nisms by which such patterns might be discussed and incorporated in building design, again as informed by considerations of complexity theory.

This discussion of architectural patterns is based partly on what has become both a popular and classic text on design patterns by Christopher Alexander and his colleagues (Alexander, Ishikawa, \& Silverstein, 1977), and on the work of Tanner and his students, Andersen and Yarbrough, who have applied some of those patterns to school architecture (Andersen, 1999; Tanner, 2000; Tanner \& Andersen, 2003; Yarbrough, 2001). Tanner's initial work involved an empirical study of 44 elementary schools with close to 23,000 students in the State of Georgia. He developed a scale to measure school design based on Alexander's patterns including green areas, quiet areas, promenades, play areas, flex zones, small group areas, large group areas, wet areas for science and art, outdoor rooms, circulation patterns, acoustics, windows, technology, pathways, living views, and natural light. After taking into account various socioeconomic variables, Tanner concluded that the best predictors of achievement in language and mathematics were pathways (schools that had clearly defined areas for freedom of movement), technology for teachers, positive outdoor spaces, and overall impression (what he called "personality of place" indicating the presence of friendly student and teacher learning environments).

At this point, I should emphasize the supreme irony in using achievement measures on standardized tests as a measure for assessing the value of architectural patterns for schooling. While Tanner's scale for assessing schools might, in fact, be representative of features of design that are in keeping with complexity science, the use of achievement standards most definitely is not. This points to a whole area of research, begging to be carried out, where other indicators are used to talk about the complexity of students' learning experiences.

Perhaps it is partly for the reason that performance on standardized achievement tests is not the best measure of learning, and perhaps it is partly because, as Tanner suggests, very few schools actually embody some of the design patterns on his scale, that some of the patterns that Tanner thought might predict performance-such as planned quiet areas-didn't seem to have an effect. Tanner's overall conclusion was that schools that were "in harmony with nature tended to have students who earned high [Iowa Test of Basic Skills] scores" (p. 321).

How do Alexander's patterns and the findings of Tanner relate to complexity science? To the architectural and pedagogical notions embedded in some of the early childhood settings examined in a previous section of this paper? Some of the key features of complex systems are now revisited with these questions in mind. 


\section{Neighbor Interactions}

The notion that freedom of movement within the school and between learning environments (pathways) was an important school feature (Tanner, 2000; Yarbrough, 2001) is completely in keeping with complexity science theory. In order for complex systems to thrive it is critical that the agents in the system come into contact with one another. In other words, neighbor interactions (Johnson, 2001) or multiple possibilities for ideas to "bump" against one another (Davis, 2004) are crucial for learning to occur. Almost the same phrase is used by Sara Snyder Crumpacker, an organizational consultant, who claims that "schools should be planned so that users 'bump into' different choices on a daily basis" (1995, p. 35, emphasis added). In order to facilitate such interactions, Crumpacker (1995) suggests that buildings should be full of variety in terms of the kinds of spaces that are provided, including informal areas to congregate, areas that are "as comfortable as our own family rooms" (p. 40). This kind of space within a learning setting is not unlike the environments of the Reggio Emilia schools described earlier.

The bumping up of ideas is also fostered by schools that have access to technology embedded throughout the building. This is something advocated by Nair (2002), a school planning consultant, who suggests that along with easy access to technology, the presence of presentation spaces, "collaborative incubators", get away spaces and niches, and display spaces would serve as important features of schools that support deeper engagement in learning. Nair points out that with ubiquitous access to wireless laptops, students will come into contact not only with those people who share the same learning space, but also, with other "classmates" who share similar interests in other parts of the world. This notion of easy access to technology is noted by educators as well (Bullock \& Foster-Harrison, 1997), and indeed, is a contemporary version of a feature of Dewey's utopian school where there would be "books everywhere" (Dewey, 1933/1989).

Teacher workrooms for research, collaborative work, and student meetings (Bullock \& Foster-Harrison, 1997; Nair, 2002) also contribute to the possibility of neighbor interactions and the bumping of ideas. Other patterns in Tanner's scale to measure school design that did not emerge as significant predictors of achievement (but may have been important had other indicators besides achievement been used) can also foster neighbor interactions, such as promenades, circulation patterns, intimacy gradients, and paths with goals.

\section{Redundancy}

One of the features of complex learning environments identified by Johnson (2001) and Davis (2004) is that of redundancy. Crumpacker (1995) refers 
explicitly to redundancy in her suggestions regarding navigation, claiming that lighting effects, visual perspectives, dimensional differences and focal points should draw people into and through a building with ease. Even where architects imagine schools without traditional classrooms made up of students in the same grade, the idea of redundancy is still achieved through modified homogeneity, such as built spaces to accommodate gradelevel teams rather than full classrooms (Day, 2000).

Redundancy is also a central feature of Waldorf schooling in the form of the highly ritualized practices and occasions. Many of these occasions are built around seasonal festivals, while others are more directly embedded in the curricular practices and materials (e.g., around water color painting). A good deal of the redundancy is also built into the architecture and physical objects (Oberman, 1997).

\section{Diversity}

If it is true that diversity is important for complexity to emerge, then the growing trend to have schools serve more than the student population is one that would support complexity. It is increasingly the case-partly because of budget cutbacks - that schools are serving a variety of groups, both during school and after school hours. These groups include parents, seniors, and special interest groups (Bogle \& Diamond, 2004).

Creating built environments (including appropriate furniture) to support multiage groupings (Day, 2000; Nair, 2002) also introduce diversity into the learning environment. Another feature of built environments that encourages diversity, especially if one thinks of learning as resting not only with the individual or even the classroom collective, but as curricular or disciplinary, is the availability of spaces that encourage different kinds of learning, much as envisaged by Dewey where he called for a variety of equipment, workshops, and laboratories to support learning (Dewey, 1933). The project rooms, kivas, and atriums proposed by Nair (2002) would contribute to this kind of curricular diversity. Again, there is a similarity here to some of the early childhood structures, such as the atelier of the Reggio Emilia schools.

\section{Pattern Recognition}

Bradley (1998) claims that thoughtful school design incorporates rich patterns throughout. He emphasizes the importance of balance, order, symmetry, rhythm, form, space, volume, and scale in his discussion of pattern. One example he gives is that of a central corridor in an elementary school where a series of arches was used by the architects to "articulate the spine, creating a syncopated rhythm that draws the occupant from one end of the building to the other" (Bradley, 1998). Some of these notions-such as bal- 
ance and pattern-have been noted by others as well. For example, Rittelmeyer (1992) surveyed hundreds of German students and concluded that school buildings that displayed a sense of balance, warmth, and pattern were regarded as attractive and inviting.

\section{Decentralized Control}

Several decades ago, architects in Scandinavia pointed to the need to change school design in two fundamental ways: to decentralize administration and teaching, and to create physical environments that allowed for teamwork and greater flexibility in learning and teaching interactions. The importance of opening the school to the larger community was also emphasized (Cold, 1986; Colven, 1990). In terms of complexity theory, this can be interpreted as including the community as one of the nested collectives involved in the generation of knowledge.

Decentralized administrative and guidance services are also espoused as important by architects with experience in non-traditional school design (Day, 2000). Earlier, I noted that the notion of decentralized control was a central feature of Waldorf schools. Perhaps not surprisingly, one of the central objectives of Waldorf schooling is to "create an environment in which the students can discover themselves" (Oberman, 1997, p. 4)—an objective that is in keeping with the theory of complexity science but distinctly out of kilter with a society that measures the success of schooling on the basis of performance on standardized tests.

\section{Cognition as both Biological and Cultural}

If the complexivists are correct in that our understanding of cognition and learning must be thought of in biological as well as cultural terms (Tomasello, 2000), then it stands to reason that the natural environment also plays a central role in learning. This we have already encountered in Froebel's kindergartens, in Steiner's schools, and in Dewey's formulations, as well as in the importance of the natural world in meaningful learning for adults. What are the implications for schools?

One obvious implication is that attention needs to be paid to natural spaces and what might be termed outdoor classrooms (Bingler, 1995). Some architects have emphasized particular forms of outdoor spaces, such as the interior courtyard (Muir, 2001). Others have simply suggested that what is important is a variety of outdoor spaces rather than distinct outdoor activity settings (Crumpacker, 1995).

To pay attention to the natural world means more than to provide outdoor spaces. It also implies attention to a larger aesthetic. As Dewey himself suggested, learning is enhanced when the aesthetic elements are at- 
tended to, and indeed, that the aesthetic brings together a balance and order to daily life (Dewey, 1933/1989).

\section{Cognition as Nested in Learning Collectives}

I have stressed that complexity science demonstrates how collectives learn and know. This leads, quite naturally, to the claim that communities should be fully involved in the design process. The idea that participatory design is an important way to proceed with school architecture was suggested earlier in the paper. But it is critical that community involvement is truly participatory, and not merely participation after the fact. As Bingler (2002), President of Concordia Architects, and consultant to the US Department of Education blandly states:

Communities have become skeptical of the public hearing process. They have attended too many meetings where they reviewed some concept, gave their opinion, and then were ignored. They're called in after all the decisions have been made and are told, "Here's where the school's going to be located and here's a beautiful picture of it. Hope you like it." At that point, who's going to stand up and say, "I think we need four small schools instead of this one big school"?

Carey (2001) puts it even more succinctly, “Don't try to fool the public by holding a hearing when decisions are already cast in concrete. I have attended hearings like that and don't blame parents for pointing out the truththat they are involved only for a show of involvement."

Of course, if one is really serious about the community being involved in the design process, then that community should also include the teachers (Hubler, 1997) and the students themselves. Indeed, it would appear that there are many long term benefits to students who are involved in the design of learning spaces, including a sense of confidence and skill in utilizing built and natural environments in achieving one's goals (Hart, 1987; Killeen, Evans, \& Danko, 2003).

\section{Concluding Remarks}

As Bradley (1998) has so forcefully stated,

An impenetrable roof, solid walls, and an adequate mechanical system continue to be the standard even when designing new facilities. We are being presented with an opportunity to design the next generation of America's schools, and yet we have not given enough thought to how architecture could be used as an effective medium for enhancing teaching and learning.

Bradley goes so far as to suggest that educational reform cannot happen in the buildings that currently exist, and that it is the job of both archi- 
tects and educators to come together to determine how the natural and built environments can change in concert with educational philosophy. I began this paper by strongly criticizing the transmission model of teaching and the standardized testing that goes with it, following with the claim that the kind of learning that we do when no one is watching, the kind of learning that is involved in dynamic complex systems, the kind of learning that often happens in the early childhood settings of Reggio, Waldorf, and Froebel schools, is more in keeping with what it means to be human. Meek (1995) echoes those sentiments in her observation that

[I]t's not easy for people to attach deep meaning-a sense of belonging, affection, and loyalty - to the index of leading economic indicators [or other standardized measures.] But it is easy, in fact, inevitable, to attach deep meaning to the school where you first trudged up the steps to make friends and meet teachers; where, perhaps, you ... tried out for the senior play; understood the beauty of algebra or the chemistry of cooking; or began to see the connections between the Elizabethan origins of the settlers of your state and the language of your family... for these reasons, the school as a place is a fertile ground for the creation of deep meaning and, therefore, of symbolic importance in the hearts and minds of people." (p. vi).

It was noted at the outset that, on average, construction begins on two new schools in the United States every day. An extraordinary number of students and teachers will be affected by these new buildings, and these effects will continue for at least 50 years as most schools enjoy a half-century of occupancy (Honeyman, 1998). With inventive design strategies and careful use of resources, construction costs for schools designed to take into account the features of complexity, the best of early childhood practices, and Dewey's aesthetic criteria, need not be more than costs associated with conventional schools (Boss, 2001a; Hyer, 2001; Nair, 2002; Reicher, 2000). With apologies to Winston Churchill, it is time to heed, more seriously, the notion that first we shape our schools, and afterwards our schools shape us. Schools can and ought to shape learners and ideas in ways that are ever expanding, leading to unpredictable and imaginative encounters with people and ideas.

\section{Acknowledgments}

This work was supported in part by a grant from the Social Sciences and Humanities Research Council of Canada. It was also made possible by the daily and loving support of Gary Rasberry. I am indebted to Brent Davis for introducing me to complexity science, to Gary Kembel for supporting my studies in architecture, to Brenda Reed for providing a staggering number reference materials, and to David Murphy Haglund for expanding my views of the possible. 


\section{References}

Alexander, C., S. Ishikawa, and M. Silverstein. A Pattern Language: Towns, Buildings, Construction. NY: Oxford University Press, 1977.

Andersen, S. "The Relationship Between School Design Variables and Scores on the Iowa Test of Basic Skills." PhD diss., University of Georgia, Athens, GA, 1999.

Barnard, H. School Architecture. Cincinnati, OH: H.W. Derby \& Co., 1848.

Berner, M. M. “Building Conditions, Parental Involvement, and Student Achievement in the District of Columbia Public School System." Urban Education 28, no. 1 (1992): 6-29.

_. "Buildings Matter: The Connection Between School Building Conditions and Student Achievement in Washington, DC." In Designing Places for Learning, edited by A. Meek, 85-87. Alexandria, VA: Association for Supervision and Curriculum Development, 1995.

Bingler, S. "Place as a Form of Knowledge." In Designing Places for Learning, edited by A. Meek, 23-30. Alexandria, VA: Association for Supervision and Curriculum Development, 1995.

_ . "The School Construction News and Design Share Awards 2001 Commentary." 2001, http:/ / designshare.com/Awards/2001/Commentary.htm (accessed 2004 Nov 25). . "Designing Public Schools." Connections 9, no. 1 (2002): 14-16.

Bogle, R. E., and B. M. Diamond. "Schools as Centers of Community: A New Approach to School Design Serves Students and Communities Alike." Learning by Design, (2004), http://www.asbj.com/lbd/2004/essay-schools-as-centers.html (accessed 2004 Nov 25).

Borgia, E. "Impressions of Reggio Emilia." 1991, ERIC Document Reproduction Service, ED 338386.

Boss, S. "Breaking out of the Box." Northwest Education Magazine 6, no. 4, Summer 2001, http:/ / www.nwrel.org/nwedu/summer01/ (accessed 2004 Nov 25).

- (2001b). "Schoolyard Lessons." Northwest Education Magazine 6, no. 4, Summer 2001, http:// www.nwrel.org/nwedu/summer01/ (accessed 2004 Nov 25).

Bullock, A. A. and E. S. Foster-Harrison. "Making the Best Decisions: Designing for Excellence!" Schools in the Middle 7, no. 2 (1997): 37-39.

Bradley, W. S. "Expecting the Most from School Design." Unpublished manuscript, Thomas Jefferson Center for Educational Design, University of Virginia, Charlottesville. 1998.

Capra, F. The Web of Life: A New Scientific Understanding of Living Systems. NY: Anchor Books, 1996.

Carey, K. K. "Hearing the Public Voice: Involving the Community in School Planning." Learning by Design, (2001), http://www.asbj.com/lbd/2001/inprint/public.html (accessed 2004 Nov 25).

Chan, T. C. "Physical Environment and Middle Grade Achievement." 1980, ERIC Document Reproduction Service, ED 198645.

Cold, B. "Architecture as a Quality in the Learning and Teaching Process." 1986, ERIC Document Reproduction Service, ED 284345)

Colven, R. 1990. "The Quality of the Physical Environment of the School and the Quality of Education." Conclusions of a Seminar Lindingo, Sweden, 17-21 October 1988, ERIC Document Reproduction Service, ED 324791.

Crumpacker, S. S. “Using Cultural Information to Create Schools that Work." In Designing Places for Learning, edited by A. Meek, 31-42. Alexandria, VA: Association for Supervision and Curriculum Development, 1995. 
David, T. G. and C. S. Weinstein. “The Built Environment and Children's Development.” In Spaces For Children: The Built Environment And Child Development, edited by C.S. Weinstein and T.G. David, 3-40. New York: Plenum, 1987.

Davis, B. Inventions Of Teaching: A Genealogy. Mahwah, NJ: Lawrence Erlbaum Associates, 2004.

Davis, B., and D. Sumara. "Challenging Images Of Knowing: Complexity Science And Educational Research." Qualitative Studies in Education, in press.

Davis, B., and R. Upitis. "Pending Knowledge: On The Complexities Of Teaching And Learning." Journal Of Curriculum Theorizing 20, no. 3 (2004): 113-128.

Day, C. W. (2000). “Trends In School Design." Learning By Design, (2000), http://www.asbj.com/lbd/2000/00inprint/00day.html (accessed 2004 Nov 25).

_- - (2001). "Rethinking School Design." Learning By Design, (2000), http:// www.asbj.com/lbd/2001/inprint/ reviewers.html (accessed 2004 Nov 25).

Dewey, J. The Child And The Curriculum And The School And Society. 1900. Reprint, London: The University of Chicago Press, 1956.

Dewey, J. (1933/1989). “Dewey Outlines Utopian Schools.” In Volume IX: The Later Works 1925-1953. 1933-1934, edited by J. Boyston, 136-140. Carbondale and Edwardsville: Southern Illinois University Press.

Dudek, M. Kindergarten Architecture: Space For The Imagination. $2^{\text {nd }}$ Ed. Independence, KY: Spon Press, 2001.

Fiske, E. B. “Systemic School Reform: Implications For Architecture.” In Designing Places For Learning, edited by A. Meek, 1-10. Alexandria, VA: Association for Supervision and Curriculum Development, 1995.

Fleener, J. Curriculum Dynamics: Recreating Heart. New York: Peter Lang, 2002.

Gandini, L. "Educational And Caring Spaces." In The Hundred Languages Of Children: The Reggio Emilia Approach-Advanced Reflections. $2^{\text {nd }}$ Ed., edited by C. Edwards, L. Gandini, and G. Forman, 161-178. Greenwich, CT: Ablex Publishing, 1998.

Gardner, H. Intelligence Reframed : Multiple Intelligences For The 21st Century. New York: Basic Books, 1999.

General Accounting Office. School Facilities: America's Schools Not Designed Or Equipped For 21 $1^{\text {st }}$ Century. (GAO/HEHS-95-95), April, USGAO, Washington, DC, 1995.

Hart, R. A. "Children's Participation In Planning And Design: Theory, Research And Practice." In Spaces For Children: The Built Environment And Child Development, edited by C. S. Weinstein and T. G. David, 217-237. New York: Plenum, 1987.

Hathaway, W. "Effects Of School Lighting On Physical Development And School Performance." The Journal Of Educational Research 88, no. 4 (1995): 228.

Herrington, S. "Kindergarten: Garden Pedagogy From Romanticism To Reform." Landscape Journal 20, no. 1, (2001): 30-47.

Hill, F. “Harmony In Design: It's A People Process!" Schools In The Middle 7, no. 2 (1997): 34-36.

Honeyman, D. S. “The Condition Of America's Schools.” School Business Affairs 64, no. 1 (1998): 8-16.

Hubler, G. L. "Becoming A Voice In School Facilities Design." Schools In The Middle 7, no. 2 (1997): 28-33.

Hyer, T. (2001). “Designing Places For Discovery." Northwest Education Magazine 6, no. 4, Summer 2001, http: / / www.nwrel.org/ nwedu/summer01/ (accessed 2004 Nov 25).

Johnson, S. Emergence: The Connected Lives Of Ants, Brains, Cities, And Software. New York: Scribner, 2001. 
Killeen, J. P., G.W. Evans, and S. Danko. "The Role Of Permanent Student Artwork In Students' Sense Of Ownership In An Elementary School." Environment And Behavior 35, no. 2 (2003): 250-263.

Kolleeny, J. “K-12 Schools: As Good As It Gets." Architectural Record 191, no. 3 (2003): 131.

Lakoff, G., and M. Johnson. Philosophy In The Flesh: The Embodied Mind And Its Challenge To Western Thought. New York: Basic Books, 1999.

Lamm, Z. 1986. "The Architecture Of Schools And The Philosophy Of Education." Paper Presented At The Edusystems 2000 International Congress On Educational Facilities, Values, And Contents, Jerusalem, Israel, November 16-21, 1986. ERIC Document Reproduction Service, ED 283287.

Lezotte, L. W., and J. Passalacqua. 1978. “Individual School Buildings Do Account For Differences In Measured Pupil Performance." ERIC Document Reproduction Service, ED 164695.

Luckiesh, M., and F. K. Moss. "Effects of classroom lighting upon educational progress and visual welfare of school children." Illumination Engineering 35, (1940): 915-938.

Maturana, H. R. and F. J. Varela. The Tree Of Knowledge: The Biological Roots Of Human Understanding. Boston: Shambala, 1998.

Muir, M. "A Model Program In A Remodeled Building." Northwest Education Magazine 6, no. 4, Summer 2001, http: / / www.nwrel.org/nwedu/summer01/ (accessed 2004 Nov 25).

Nair, P. 2002. "But Are They Learning? School Buildings-The Important Unasked Questions." Paper Presented At The International Workshop On Educational Infrastructure, Guadalajara, Mexico, Feb, 2002. http:/ / www.designshare.com/Research/Nair/Are_They_Learning.htm (accessed 2004 Nov 25).

Oberman, I. 1997. Waldorf History: Case Study Of Institutional Memory. Paper Presented At The Annual Meeting Of The American Education Research Association. Mar, 1997, ERIC Document Reproduction Service, ED 409108.

Papert, S. The Children's Machine: Rethinking School In The Age Of The Computer. New York: Basic Books, 1993.

Patteson, A., R. Upitis, and K. Smithrim. "Sustainable Teacher Development In And Through The Arts." In Proceedings Of The International Society For Education Through Art 31 "World Congress. New York City, August, 2002.

Peters, P. “Here For The Children.” Texas Architect 53, no. 1 (2003): 22-25.

Plympton, P., S. Conway, and K. Epstein. “ Daylighting In Schools: Improving Student Performance And Health At A Price Schools Can Afford." Paper Presented At The American Solar Energy Society Conference, Madison, Wisconsin, June 16, 2000.

Reicher, D. "Nature's Design Rules: Leading The Way Toward Energy-Efficient Schools." Learning By Design. (2000), http:/ / www.asbj.com/lbd/2000/00inprint/00reicher.html (accessed 2004 Nov 25).

Rice, A. J. "What Research Knows About Color In The Classroom." Nation's Schools 52, no. 5, (1953): 1-8.

Rittner-Heir, R. M. “Color And Light In Learning." School Planning And Management 41, no. 2, (2002): 60-61.

Rittelmeyer, C. 2002. "Healthy Schools." Paper Presented At The International Seminar Organized By The Austrian Federal Ministry Of Education And Art, The Austrian Institute For School And Sports Facilities, And The Organisation For Economic Cooperation And Development (OECD) Programme On Educational Building, Vienna, 
Austria, October 5-8, 1992, ERIC Document Reproduction Service, ED 355646.

Romney, B. M. 1975. “The Effects Of Windowless Classrooms On The Cognitive And Affective Behavior Of Elementary School Students." ERIC Document Reproduction Service, ED 126622.

Rubin, J. S. Intimate Triangle: Architecture Of Crystals, Frank Lloyd Wright, And The Froebel Kindergarten. Huntsville, AL: Polycrystal Book Service, 2002

Rudolf Steiner Farm School. Rudolf Steiner Farm School, Hawthorne Valley. Ghent, NY: Steiner Farm School, 1979.

Sherman, L. "Lighting The Way To Learning." Northwest Education Magazine 6, no. 4, Summer 2001, http:/ / www.nwrel.org/nwedu/summer01/lighting way.html (accessed 2004 Nov 25).

Tanner, C. K. “The Influence Of School Architecture On Academic Achievement." Journal of Educational Administration 38, no. 4 (2000): 309-330.

Tanner, C. K. and S. Andersen. "Toward A Pattern Language Theory Of Middle School Design." Educational Planning 13, no. 3 (2002): 3-20.

Tanner, C. K. and S. Langford. 2003. The Importance Of Interior Design Elements As They Relate To Student Outcomes. Dalton, GA: Carpet and Rug Institute, ERIC Document Reproduction Service, ED 478177.

Tarr, P. Aesthetic code in early childhood classrooms: What Art Educators Can Learn From Reggio Emilia. Minneapolis, MN: Design Share, Inc., 2001. http:// www.designshare.com/Research/Tarr/Aesthetic Codes 1.htm (accessed 2004 Nov 25).

Taylor, A. "How Schools Are Redesigning Their Space." In Designing Places For Learning, edited by A. Meek, 67-76. Alexandria, VA: Association for Supervision and Curriculum Development, 1995.

Tomasello, M. The Cultural Origins Of Human Cognition. Cambridge, MA: Harvard University Press, 2000

Uline, C. L. “School Architecture As A Subject Of Inquiry." Journal Of School Leadership 7, no. 2 (1997): 194-209.

Upitis, R. “Spheres Of Influence: The Interplay Between Music Research, Technology, Heritage, And Music Education." International Journal of Music Education 37, no. 1 (2001): 44-58.

_. "Making Art, Making Connections." Journal Of The Canadian Association For Curriculum Studies 1, no. 2 (2003): 1-7.

_. "In Praise Of Romance." Journal Of The Canadian Association For Curriculum Studies 1, no. 1 2003):

Yarbrough, K. A. “The Relationship Of School Design To Academic Achievement Of Elementary School Children." Ph.D. diss., University of Georgia, 2001. ERIC Document Reproduction Service, ED 475272.

\section{About the Author}

Rena Upitis is Professor of Arts Education at Queen's University. Her research interests range from studying children's invented music notations to examining how computer games can enhance children's understanding of mathematics and science, and she has published and lectured widely (http:/ / www.educ.queensu.ca/ arts/). Rena's current passion is the study of architecture; she is presently enrolled as a student in the Residential Design program at Loyalist College. 